\title{
Exploration on practical teaching system of administration based on the innovative talent training
}

\author{
Baohua Cui \\ Economic Management Department, Jilin Agricultural University, \\ Changchun, China \\ Email: cbhjlau@yeah.net
}

\begin{abstract}
Keywords: innovation talent; experiment teaching system; the discipline of economy and management
\end{abstract}

\begin{abstract}
The practice teaching plays the important role in training applied undergraduate people who major in economy and management .Around the optimization of experiment teaching program, the development of multi-specialty simulation training platform, and the construction of economic management multi-specialty sharing experiment teaching system are described.
\end{abstract}

\section{Introduction}

\begin{abstract}
"Several opinions on comprehensively improving the quality of higher education by ministry of education" emphasizes: strengthen practical education, formulate measures to strengthen the educational work of university practice, combine professional features with requirements of personnel training, increase the proportion of practice teaching, ensure the necessary credits (hours) of all kinds of professional practice teaching, enhance the level of experimental teaching. It is emphasized in the "Opinions on the implementation of the undergraduate teaching quality and teaching reform project of higher universities" of the ministry of education and the ministry of finance that we should vigorously strengthen the practice teaching reform, promote reform and innovation of practical teaching pattern in colleges and universities, promote the cultivation of students' interest in independent innovation and their ability, stimulate students' interests and potential, and cultivate college students' team cooperation consciousness and innovation spirit. Establish professional practice teaching system of administration with the goal of cultivating the innovative practice ability. Based on this, this paper takes the innovation of the practice teaching system of administration major as a starting point and aims to comprehensively improve students' practical application ability. It actively explores the construction of a practice teaching system shared by administration and other majors in order to realize the goal of training senior applied, compound, and innovative talents with "wide knowledge, thick foundation, strong ability and high quality"$^{\prime 1]}$.
\end{abstract}

\section{Difficulties and challenges faced by teaching platform of administration practice under the goal of innovative talents training}

With the development of knowledge economy, the social requirement for talents has transformed from proper majors to comprehensive quality and creative ability. That is to say that to cultivate students' practical innovation ability is the foundation of the society for college students and practice teaching is the important platform of improving students' practical innovation ability. However, in today's colleges and universities, the teaching platform of administration practice is facing many difficulties and challenges.

\section{Management system is not sound.}

The practice teaching platform of high level not only includes the support of equipment, infrastructure and other hard conditions but also contains the dependence on soft resources of the experimenter literacy, value concept and the spiritual pursuit manifested in the lab environment atmosphere and advocated by themselves. At present, the experiment personnel quality is low and 
the team concept is stiff. Communication and cooperation between jobs and posts are less and the purchase of lab instrument and apparatus is duplicated and the management process is cumbersome, inefficient and lacks supervision ${ }^{[2]}$. These phenomena have seriously affected the construction of practical teaching platform and become one of the obstacles for the development of practice teaching in colleges and universities.

\section{Laboratory construction lacks overall planning.}

The development of education is vigorous and the enrollment scale is enlarging. New majors keep increasing and there is no overall coordination between each lab. The function of the laboratory is ineffective and the utilization ratio is low and its investment benefit is also poor. Builders focus on the concept of "I have whatever people have" too much instead of the concept "I have what people do not have", which results in the repetitive construction of some subjects in the overall layout is too serious and eventually be eliminated due to their losing of characteristics.

\section{Practice teaching idea is lagging behind.}

The education system reform encourages some schools to build new laboratories of high levels. But influenced by traditional education concept, they still think practice teaching is annexed to theory teaching and is dedicated to serving theory teaching and is dispensable. In addition, practice teaching still regards teachers as the main part and lacks the cultivation of students' ability to independently analyze and solve practical problems. The sharp contrast and obvious contrast are formed between old ideas and the call of the Times to advanced laboratories.

\section{The experimental technical personnel's salary is not high.}

No matter what high technology and qualifications they have, technical personnel are only the teaching "auxiliary" at best and play a supporting role. Their welfare benefits and title determining are relatively backward compared with full-time teachers and administrative leaders, which causes talents' unwillingness to work in the experiment center or their taking the experiment center as the springboard to other positions. Moreover, the laboratory work intensity is relatively large. Worse treatment and unreasonable examine and other phenomena lead to the inequality on how much one does which dampened the enthusiasm of technical personnel.

\section{The construction of practical teaching system of administration under the goal of innovative talents training}

\section{Optimize practice teaching link of administration and other professions.}

The first step of the sharing of practice teaching system among administration and other professions is to optimize practice teaching link of administration and other professions to break the existing fragmented practice teaching system among the professions. Specifically speaking, realize the sharing of existing resources of practice teaching around the knowledge experiment, course experiment and comprehensive experiment. Realize the sharing of teaching platform of multi-profession and multidisciplinary around multi-professional mimic training and school internal mimic training. Form innovation and entrepreneurship center on innovation, entrepreneurial talent training and vocational evaluation, etc. In the end, form the practice teaching course system effectively combined by high-quality practical teaching resource sharing, multi-professional comprehensive training, professional training, and course experiment to cultivate students' application ability of applying knowledge into actual work, comprehensive ability, cooperation ability, and their judgment ability, decision-making ability and innovation ability in the application process $^{[3]}$.

\section{Development multi-professional mimic training platform of administration.}

Establish a highly mimic economic environment through multi-professional mimic training platform of administration and guide training students to conduct virtual enterprise management of multi-roles under the assistance of the corresponding software support platform. Experience the activity of the whole cycle from establishing and managing the enterprise to the participation and competition by accomplishing the role play of the enterprise within the mimic business environment and deepen the understanding of the economic environment and knowledge of industry domain. In addition, through the competition and cooperation between enterprises, the business processing 
ability management consciousness and business communication skills of students can be comprehensively investigated.

\section{Construct innovative undertaking training center.}

On the basis of realizing multi-professional mimic training of administration, combine innovation entrepreneurship education and training and take the experiment center, campus practice base, and entrepreneurial innovation center as the public demonstration base to as cultivate compound, applied and innovative talents to maximize the use of school education resources and optimize personnel training. Build innovative and entrepreneurial training center of multi-courses, multi-profession, and multidiscipline to provide public practice service for local area and even the whole country ${ }^{[4]}$.

\section{Safeguards for the construction of professional practice teaching system of administration}

Whether the professional practice teaching system of administration can achieve the practice teaching effect finally and realizes the talents training target or not depends on teaching staff and the practice teaching environment.

Strengthen the practice teaching staff and enhance their practice teaching ability.

Strengthen the cultivation of the existing practice teachers and encourage theoretical teachers to go out to the enterprise to participate in the actual work, consultation, project development or employees training and accumulate professional skills and practical experience needed for teaching and improve the practice ability. At the same time, promote teachers to carry out applied research, encourage the close combination of teachers' scientific research work and its practicability. Speed up the construction of part-time teachers and hire experienced business backbones as part-time internship guidance teacher to organize a practice teaching faculty with full-time as the main part and the combination of full-time and part-time.

Strengthen the construction of school internal laboratory and external practice base and construct the practice teaching platform in and out of school.

Practice teaching platform is the material guarantee of applied undergraduate practical teaching system of administration and the practice teaching platform construction is an important part of the practice teaching system. Aiming at the characteristics of the practical teaching of administration, it is very necessary to actively construct the practice teaching platform in and out of school.

Try out the opening laboratory management system and promote open laboratory

Open laboratory is an important content of practice teaching reform and it has changed the old traditional teaching model of passive and enclosed pattern and attracted students to carry out the research and practice in the laboratory in extracurricular time which turns the laboratory into the base of knowledge application, integration and innovation. For example: mimic laboratory by imitating enterprises' actual management and operation process, the laboratory that can carry out the work of scientific research and innovation, the laboratory that can carry out the competition of science and technology, the laboratory that can carry out the training of students' professional ability and post practice ability, etc.

Establish a stable practice base outside the school and realize the unity of production, study and research.

In order to satisfy the need of training applied talents of administration practice teaching condition, form a good cooperation with enterprises and institutions and establish a relatively stable practical teaching base of comprehensiveness, specialty and production-study-research combination, so that the students can exercise and practice in a planned way. In addition, considering the more and more prominent effect of the trade association on the development of industry, the association possesses the unique resources and advantage that are closely linked with the enterprise. So we should strengthen the cooperation with the industry association and provide accurate technical support and the latest knowledge requirements for professional practice learning. Provide services for enterprises by using industry association platform and carry out the scientific research project to make the practice teaching fresher ${ }^{[5]}$. 


\section{Conclusion}

The administration profession is the main force of the cultivation of applied undergraduate talents in our country. Strengthening practice teaching and improving the quality of applied talents training of administration are the demand of the society and also the result of the law of higher education and teaching. The construction and practice of practical teaching system is the exploration of this kind of talents cultivation in the practical teaching work, which is of great significance to deepen the understanding on practice teaching law of administration for educators and enlarge the funds for practice teaching and reform practice teaching mode. With people's more understanding on this regulation, the practice teaching work will be improved.

\section{References}

[1] LI Yan.The Problems and $\mathrm{R}$ eforming Practice of Economic and Management Cross-disciplined Practice in Colleges and Universities [J]. China Management Informationization,2012,15( 21) : 93-94.

[2] YI Yong-xi.The Problems and Countermeasures of Practical Teaching in Applied University Economics and Management Specialty $\quad[\mathrm{J}]$. Education and Teaching Forum,2013( 40) : 113-115.

[3] JIN Tao,CHEN Yuan. The Features and Trend of Practical Teaching in Economic and Management Specialty [J]. China Higher Education, 2012( Z1) : 71-72.

[4] HE Jin-zhe, XU Jing-bo. Study and Exploration on Resource Sharing Mechanism of Laboratory [J] . Laboratory Science,2010,13 ( 6) :132-135.

[5] ZENG Xiao-bin. Deeping Experiment and Practice Teaching Reform and Improving the Cultivation Quality of Application oriented Talents $[\mathrm{J}]$.Research and Exploration in Laboratory, 2010, 29( 2) : 1-3. 